\title{
PENGARUH MOTIVASI, KEMAMPUAN MANAJERIAL KEPALA SEKOLAH DAN IKLIM ORGANISASI TERHADAP KINERJA GURU DI SEKOLAH MENENGAH KEJURUAN ( SMK ) YPT PANGKALAN BERANDAN KABUPATEN LANGKAT
}

\author{
Agus Salim \\ Universitas Islam Sumatera Utara \\ Agussalim@gmail.com
}

\begin{abstract}
ABSTARCT
The formulation in this research is how the influence of motivation, school head and the organizational climate simultaneously to the performance of teachers in vocational high School (SMK) YPT Pangkalan Berandan District, and the purpose of this research is To know and analyze the influence of motivation, school head and climate of the organization simultaneously to the performance of teachers in vocational high School (SMK) YPT Pangkalan Berandan and Langkat district.This research is a quantitative descriptive study. Data collection techniques are conducted through interviews, questionaire questions and documentation studies. Sample in this study as many as 44 teachers in vocational high School (SMK) YPT Pangkalan Berandan and Langkat district. Variables are measured at Likert scale. Hypothesis testing using multiple linear regression analyses through F-test and T-Test. The results of the test in unison showed that the principal motivation and managerial ability of the school as well as the organizational climate has a significant effect on the performance of Vocational High School (SMK) YPT basis, and the value of coefficient of determination of 0.840 or $84.0 \%$. Partially, motivation (X1) has a positive and significant effect on the performance of Vocational secondary school (SMK) YPT, and with a regression coefficient value of 0452 or $45.2 \%$. The principal's managerial ability (X2) has a positive and significant impact on the performance of Vocational secondary school (SMK) YPT Berandan and with a regression coefficient value of 0407 or $40.7 \%$. Climate Organization (X3) positively and significantly affect the performance of vocational secondary school (SMK) YPT, and with a regression coefficient value of 0197 or 19.7\%. The highest value of a regression coefficient is the master motivation of 0452 or $45.2 \%$.
\end{abstract}

Keywords: motivation, managerial ability, organizational climate, performance

ABSTRAK : Rumusan pada penelitian ini adalah bagaimana pengaruh motivasi, menajerial kepala sekolah dan iklim organisasi secara simultan terhadap kinerja guru di Sekolah Menengah Kejuruan (SMK) YPT Pangkalan Berandan Kabupaten Langkat, dan tujuan penelitian ini adalah untuk mengetahui dan menganalisis pengaruh motivasi, menajerial kepala sekolah dan iklim organisasi secara simultan terhadap kinerja guru di Sekolah Menengah Kejuruan (SMK) YPT Pangkalan Berandan Kabupaten Langkat. Penelitian ini merupakan penelitian deskriptif kuantitatif. Teknik pengumpulan data dilakukan melalui wawancara, daftar pertanyaan (questionaire) dan studi dokumentasi. Sampel dalam penelitian ini sebanyak 44 orang Guru di Sekolah Menengah Kejuruan (SMK) YPT Pangkalan Berandan Kabupaten Langkat. Variabel diukur dengan skala Likert. Pengujian hipotesis menggunakan analisis regresi linear berganda melalui uji $F$ dan uji t. Hasil uji secara serempak menunjukkan bahwa Motivasi dan Kemampuan Manajerial Kepala Sekolah serta Iklim Organisasi berpengaruh signifikan terhadap Kinerja Guru Sekolah Menengah Kejuruan (SMK) YPT Pangkalan Berandan dengan nilai koefisien determinasi sebesar 0,840 atau 84.0\%. Secara parsial, Motivasi $\left(X_{1}\right)$ berpengaruh positif dan signifikan terhadap Kinerja Guru Sekolah Menengah Kejuruan (SMK) YPT Pangkalan Berandan dengan nilai koefisien regresi sebesar 0.452 atau $45.2 \%$. Kemampuan Manajerial Kepala Sekolah $\left(\mathrm{X}_{2}\right)$ berpengaruh positif dan signifikan terhadap Kinerja Guru Sekolah Menengah Kejuruan (SMK) YPT Pangkalan Berandan dengan nilai koefisien regresi sebesar 0.407 atau 40.7\%. Iklim Organisasi $\left(X_{3}\right)$ berpengaruh positif dan signifikan terhadap Kinerja Guru Sekolah Menengah Kejuruan (SMK) YPT Pangkalan Berandan dengan nilai koefisien regresi 
sebesar 0.197 atau 19.7\%. Nilai koefisien regresi yang paling tinggi adalah Motivasi Guru sebesar 0.452 atau $45.2 \%$.

\section{Kata kunci : motivasi, kemampuan manajerial, iklim organisasi, kinerja}

\section{Pendahuluan}

Mutu pendidikan akan tercapai apabila komponen yang terdapat dalam meningkatkan mutu pendidikan memenuhi syarat tertentu. Komponen yang berperan dalam peningkatan mutu pendidikan salah satunya adalah tenaga pendidik bermutu yaitu yang mampu menjawab tantangan-tantangan dengan cepat dan bertanggung jawab. Tenaga pendidik mempunyai peran yang sangat strategis dalam pembentukan pengetahuan, keterampilan, dan karakter peserta didik, karena itu tenaga pendidik yang professional akan melaksanakan tugasnya secara professional sehingga menghasilkan siswa yang lebih bermutu.

Dalam perkembangan pembangunan di Indonesia di masa mendatang pendidikan merupakan kunci pokok dimana pendidikan diharapkan dapat menjadi penggerak masyarakat Indonesia untuk meningkatkan kualitas keberadaannya serta mampu berpartisipasi dalam gerak pembangunan. Kepala sekolah, guru dan tenaga kependidikan lainnya adalah tenaga profesional. Oleh karena itu, mereka harus terdidik dan terlatih secara akademik dan profesional serta dapat pengakuan formal sebagaimana mestinya (Depdiknas, 2004: 1) dan profesi nengajar harus memiliki status profesi yang membutuhkan pengembangan (Tilaar, 2011: 142). Menyadari hal tersebut, maka pihak Depdiknas melakukan program sertifikasi berupa akta mengajar bagi lulusan ilmu kependidikan maupun non kependidikan yang akan menjadi pendidik. Untuk menjadi guru profesional, guru harus memenuhi kualifikasi akademik minimum dan sertifikasi akademik minimum dan sertifikasi sesuai dengan jenjangkewenangan mengajar (UU. RI. NO. 20 tahun 2003 pasal 42 dan PP. RI No 19 tahun 2005 Bab pasal 28).

Diantara faktor penting yang mempengaruhi kinerja guru adalah kemampuan kepala sekolah seperti yg di utarakan oleh menurut Robin (2012:3) adalah "kemampuan untuk mempengaruhi suatu kelompok ke arah tercapainya tujuan". Setiap manusia pada hakikatnya adalah pemimpin dan setiap manusia akan diminta pertanggung jawaban atas kepemimpinanya kelak. Manusia sebagai pemimpin minimal mampu memimpin dirinya sendiri. Setiap organisasi harus ada pemimpinnyan, yang secara ideal dipatuhi dan disegani bawahanya. Organisasi tanpa pemimpin akan kacau balau. Oleh karena itu, harus ada pemimpin yang memerintah dan mengarahkan bawahanya untuk mencapai tujuan individu, kelompok, dan oerganisasi. Peran seorang pemimpin dalam sebuah entitas atau organisasi sangat diperlukan dalam rangka mengarahkan bawahannya untuk mencapai tujuan organisasi. Oleh karena itu, jika tidak ada kepemimpinan yang baik, maka tujuan organisasi pun akan sulit dicapai.

Diperlukan keterampilan manajerial tertentu untuk melaksanakan tugas-tugas manajerial kepala sekolah. Menurut Paul Hersey dalam (Wahjosumidjo;2002) paling tidak ada tiga macam keterampilan manajerial yang diperlukan yaitu: (1) Keterampilan konsep; (2) Ketrampilan manusiawi/sosial; (3) Keterampilan teknik.

Keberhasilan kepala sekolah dalam meningkatkan kualitas pendidikan di lembaga yang dipimpinnya tidak terlepas dari kompetensi dan kemampuannya memainkan tugas, peran, dan fungsinya sebagai kepala sekolah. Menurut Permendiknas nomor 13 tahun 2007 tentang standar kepala sekolah, kompetensi kepala sekolah terdiri dari lima dimensi yaitu: Kepribadian, manajerial, kewirausahaan, supervisi, dan sosial.

Untuk menunjang dalam mewujudkan itu diperlukan guru yang memiliki kinerja tinggi. Guru dengan kinerja tinggi akan berusaha untuk menunjukkan prestasi yang tinggi demi meningkatkan kualitas mengajarnya sehingga mutu pembelajaran akan semakin meningkat pula. Kinerja guru akan tampak dari bagaimana guru melaksanakan tugas pokoknya. Seorang guru dituntut untuk mampu menyusun perencanaan pembelajaran dengan baik, sebab dengan perencanaan yang baik, maka guru dapat melaksanakan pembelajaran sesuai dengan tujuan yang diharapkan. Selain itu, guru yang berkinerja baik dapat melaksanakan kegiatan pembelajaran melalui penggunaan metode, media, pendekatan dan strategi sehingga siswa dapat memahami dengan baik yang disampaikan oleh guru.

Terdapat banyak faktor yang mempengaruhi kinerja mengajar guru, antara lain: kompetensi guru, motivasi kerja, kemampuan kerja, kompetensi guru, status sosial guru. Berdasarkan 
pengamatan awal yang diakukan dalam penelitian ini terhadap Sekolah Menengah Kejuruan (SMK) YPT Pangkalan Berandan Kabupaten Langkat, diperoleh gambaran bahwa sebagian guru terlihat kurang semangat dalam mengajar. Ada beberapa guru yang terlambat masuk ke dalam kelas untuk memulai pelajaran. Selain itu juga guru-guru sering berkumpul dan ngobrol di ruang guru ketika seharusnya memulai pelajaran di kelas. Hal ini menunjukkan bahwa semangat sebagian guru tersebut relatif rendah

Iklim organisasi sekolah terutama yang berkaitan dengan sarana prasarana sekolah, seperti kebersihan sekolah, kenyamanan ruang kelas serta keindahan halaman sekolah, masih sangat memprihatinkan. Disamping itu juga rerlihat beberapa siswa yang bermain diluar kelas pada saat jam pelajaran berlangsung, hal ini menunjukkan tingkat kedisiplinan sekolah relatif kurang maksimal. Dengan demikian maka diduga ada pengaruh motivasi kerja guru terhadap kondisi yang ada di sekolah tersebut..

\subsection{Rumusan Masalah}

Adanya perubahan yang selalu dihadapi oleh setiap sekolah baik yang berada diluar maupun didalam sekolah tersebut dapat menjadi hambatan demi pencapaian tujuan yang efektif dan efisien. Berdasarkan latar belakang masalah tersebut diatas, maka yang menjadi rumusan masalah dalam penelitian ini adalah, bagaimana pengaruh motivasi, menajerial kepala sekolah dan iklim organisasi secara simultan terhadap kinerja guru di Sekolah Menengah Kejuruan ( SMK ) YPT Pangkalan Berandan Kabupaten Langkat.

\subsection{Batasan Masalah}

Penelitian ini akan hanya mengkaji tentang hubungan dan kontribusi motivasi, manajerial kepala sekolah dan iklim organisasi dan kinerja guru di Sekolah Menengah Kejuruan ( SMK ) YPT Pangkalan Berandan Kabupaten Langkat.

\subsection{Hipotesis}

Berdasarkan rumusan masalah, tujuan penelitian, kajian teori, dan kerangka konseptual yang telah dikemukakan diatas, maka rumusan hipotesis penelitian ini dapat dirumuskan sebagai berikut: Motivasi, kemampuan manajerial kepala sekolah dan iklim organisasi secara simultan berpengaruh terhadap kinerja guru di Sekolah Menengah Kejuruan (SMK) YPT Pangkalan Berandan Kabupaten Langkat.

\subsection{Tujuan Penelitian}

Berdasarkan rumusan masalah penelitian sebagaimana diuraikan di atas, maka tujuan yang hendak dicapai dalam penelitian ini yaitu:

a. Untuk mengetahui pengaruh motivasi terhadap kinerja guru di Sekolah Menengah Kejuruan (SMK) YPT Pangkalan Berandan Kabupaten Langkat.

b. Untuk mengetahui pengaruh kemampuan manajerial kepala sekolah terhadap kinerja guru di Sekolah Menengah Kejuruan ( SMK ) YPT Pangkalan Berandan Kabupaten Langkat.

c. Untuk mengetahui pengaruh iklim organisasi terhadap kinerja guru di Sekolah Menengah Kejuruan ( SMK ) YPT Pangkalan Berandan Kabupaten Langkat.

d. Untuk mengetahui secara simultan hubungan motivasi, kemempuan manajerial kepala sekolah dan iklim organisasi terhadap kinerja guru di Sekolah Menengah Kejuruan ( SMK ) YPT Pangkalan Berandan Kabupaten Langkat.

\section{Metode Penelitian}

\subsection{Populasi dan Sampel}

Populasi adalah wilayah generalisasi yang terdiri atas objek/subjek yang mempunyai kualitas dan karakteristik tertentu yang ditetapkan oleh peneliti untuk dipelajari kemudian ditarik kesimpulannya. Suharyadi (2004:98). Populasi dalam penelitian ini adalah seluruh guru di Sekolah Menengah Kejuruan ( SMK ) YPT Pangkalan Berandan Kabupaten Langkat sebanyak 44 orang.

Dengan teknik penarikan sampel secara Total Sampling maka sampel dalam penelitian ini adalah seluruh populasi yaitu 44 orang guru di Sekolah Menengah Kejuruan ( SMK ) YPT Pangkalan Berandan Kabupaten Langkat.

Tabel 1. Kerangka Sampel Berdasarkan Bidang Study TP. 2018/2019

\begin{tabular}{|l|l|r|c|}
\hline No & \multicolumn{1}{|c|}{ Jabatan } & $\begin{array}{c}\text { Jlh } \\
\text { Populasi }\end{array}$ & Ket \\
\hline 1 & Guru Teknik & 21 & Diteliti \\
\hline 2 & Guru Bahasa & 7 & Diteliti \\
\hline 3 & Guru IPS & 1 & Diteliti \\
\hline 4 & Guru Kimia & 2 & Diteliti \\
\hline 5 & Guru Kewirausahaan & 1 & Diteliti \\
\hline 6 & Guru PKN & 2 & Diteliti \\
\hline 7 & Guru Agama & 3 & Diteliti \\
\hline 8 & Guru Matematika & 4 & Diteliti \\
\hline
\end{tabular}




\begin{tabular}{|c|c|c|c|}
\hline No & Jabatan & $\begin{array}{c}\text { Jlh } \\
\text { Populasi }\end{array}$ & Ket \\
\hline 9 & Guru Penjas & 1 & Diteliti \\
\hline 10 & Guru Seni Budaya & 1 & Diteliti \\
\hline 11 & Guru Prakarya & 1 & Diteliti \\
\hline \multicolumn{2}{|c|}{ Jumlah } & 44 & \\
\hline
\end{tabular}

\subsection{Uji Normalitas Data}

Uji normalitas bertujuan untuk menguji apakah dalam model regresi variabel pengganggu (residual) memiliki distribusi normal. Seperti diketahui bahwa uji " $\mathrm{t}$ " dan uji F mengasumsikan bahwa nilai residual mengikuti distribusi normal.

Dalam penelitian ini pengujian normalitas dideteksi melalui analisa grafik P-P Plot.yang dihasilkan melalui SPSS. Adapun output grafik P-P Plot seperti terlihat pada gambar dibawah ini

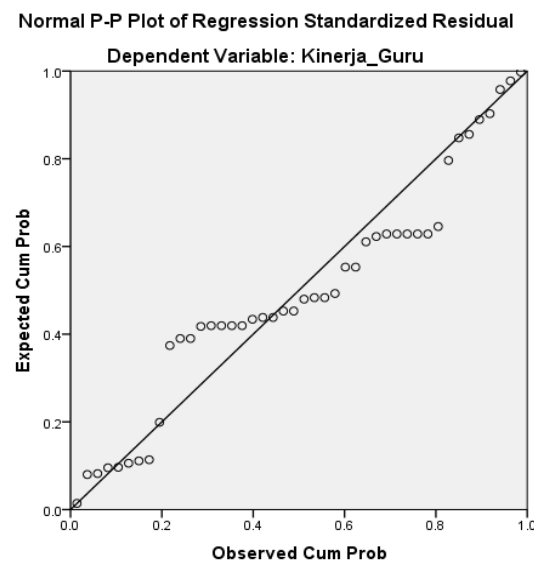

Gambar 1. Uji normalitas P-P Plot Test

Berdasarkan gambar di atas, terlihat bahwa distribusi dari titik-titik data Motivasi, Kemampuan Manajerial Kepala Sekolah, Iklim Organisasi dan Kinerja menyebar. Grafik P-P Plot diatas menunjukan bahwa sebaran data menyebar disekitar garis diagonal, sehingga asumsi normalitas dipenuhi. Maka model regresi layak dipakai untuk memprediksi Kinerja berdasarkan variabel independennya.

Berdasarkan gambar 5.2 dibawah terlihat bahwa grafik histogram memberikan pola distribusi normal tidak berpola distribusi melenceng (skweness) ke kiri atau ke kanan, maka model regresi memenuhi asumsi normalitas.

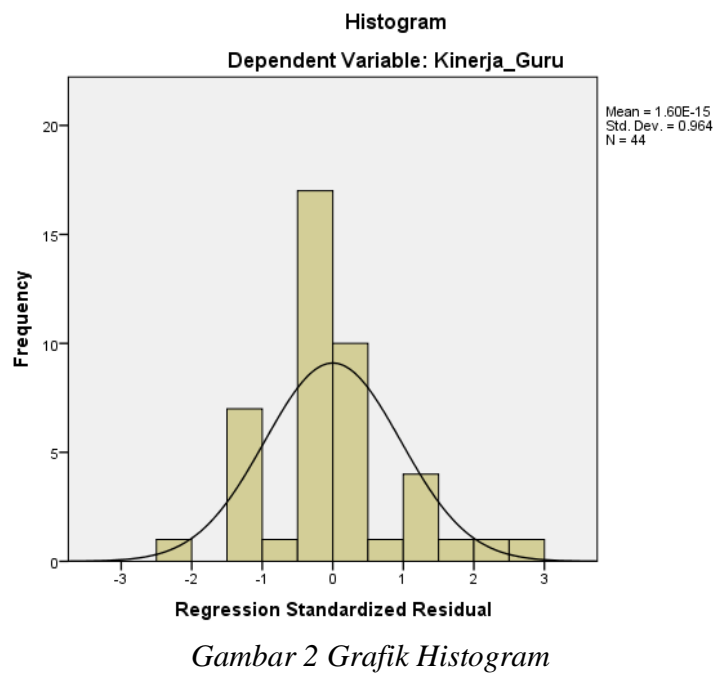

\subsection{Uji Multikolinearitas}

Metode untuk menguji ada tidaknya multikolinearitas dapat dilihat Tolerance Value dan Inflation Factor (VIF). Batas tolerance value adalah 0,10 atau nilai VIF adalah 10. Jika tolerance value $>0,10$ dan $\mathrm{VIF}<10$ maka tidak terjadi multikolinearitas dan sebaliknya jika tolerance value $<0,10$ dan VIF $>10$ maka terjadi multikoleniaritas. Hasil pengolahan dapat dilihat pada tabel berikut ini:

Tabel 2

Uji Multikolinearitas Coefficients $^{\mathrm{a}}$

\begin{tabular}{|c|c|c|}
\hline \multirow[t]{2}{*}{ Model } & \multicolumn{2}{|c|}{ Collinearity Statistics } \\
\hline & Tolerance & VIF \\
\hline (Constant) & & \\
\hline Motivasi & .299 & 3.341 \\
\hline Kemamp_Mnj & .359 & 2.787 \\
\hline Iklim_Organisasi & .732 & 1.365 \\
\hline
\end{tabular}

a. Dependent Variable: Kinerja_Guru

Berdasarkan output tabel 2, hasil perhitungan nilai variance inflaction factor (VIF) juga menunjukkan bahwa tidak ada satu variabel independen yang memiliki nilai VIF lebih dari 10. Jadi dapat disimpulkan bahwa tidak ada multikolinieritas antar variabel independen dalam model regresi.

\subsection{Uji Heteroskedastisitas}

Uji heteroskedastisitas dilakukan untuk mengetahui apakah dalam sebuah model regresi terjadi ketidaksamaan varians dari residual suatu pengamatan ke pengamatan lain. Jika varians dari residual suatu pengamatan ke pengamatan lain tetap disebut heteroskedastisitas. 
Menganalisis data dalam pengujian asumsi klasik ini, peneliti menggunakan Program Statistical Product and Service Solution (SPSS Versi 20.) for Windows dapat dilihat pada gambar 5.3 berikut ini:

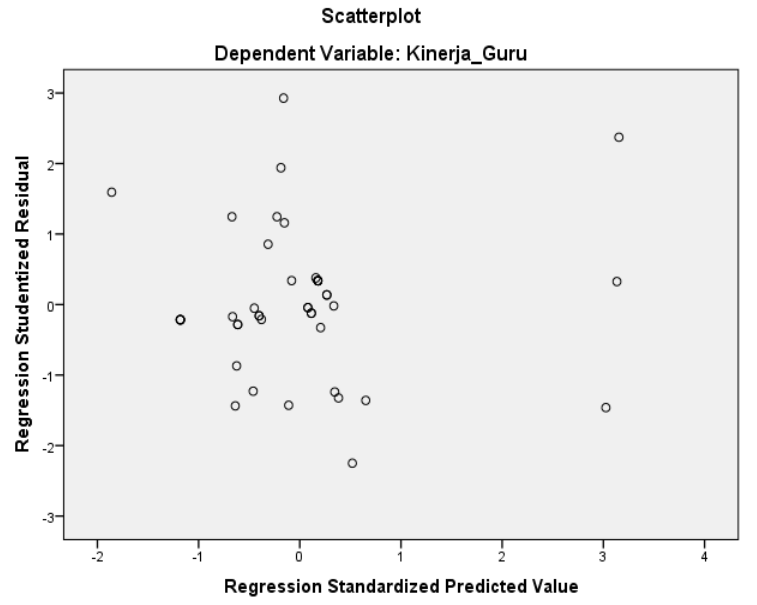

Gambar 3 Grafik scatterplot Uji Heteroskedastisitas

Tabel 4

Regresi Linear Berganda

Coefficients $^{\mathrm{a}}$

\begin{tabular}{|c|c|c|c|c|c|c|}
\hline \multirow{2}{*}{\multicolumn{2}{|c|}{ Model }} & \multicolumn{2}{|c|}{ Unstandardized Coefficients } & \multirow{2}{*}{$\begin{array}{c}\begin{array}{c}\text { Standardized } \\
\text { Coefficients }\end{array} \\
\text { Beta }\end{array}$} & \multirow[t]{2}{*}{$\mathrm{t}$} & \multirow[t]{2}{*}{ Sig. } \\
\hline & & $\mathrm{B}$ & Std. Error & & & \\
\hline \multirow{4}{*}{1} & (Constant) & 9.446 & 1.469 & & 6.432 & .000 \\
\hline & Motivasi & .395 & .101 & .452 & 3.912 & .000 \\
\hline & Kemamp_Mnj & 307 & .080 & 407 & 3.856 & .000 \\
\hline & Iklim_Organisasi & .178 & .067 & 197 & 2.663 & .011 \\
\hline
\end{tabular}

a. Dependent Variable: Kinerja_Guru

Sumber: Hasil Pengolahan SPSS 20, tahun (2019).

Berdasarkan pengolahan data yang terlihat pada tabel output kolom kedua bagian B (Unstandardized Coefficients), diperoleh persamaan regresi linier berganda yaitu:

$$
y=a+b_{1} x_{1}+b_{2} x_{2}+b_{3} x_{3}+\varepsilon
$$

$$
Y=9.446+0.395 X_{1}+0.307 X_{2}+0.178 X_{3}+\varepsilon
$$

Dengan persamaan regresi linier berganda tersebut dapat dijelaskan bahwa :

a) Nilai konstanta adalah sebesar 9.446 hal ini menyatakan bahwa jika variable Motivasi, Kemampuan Manajerial Kepala Sekolah dan Iklim Organisasi diabaikan, maka nilai Kinerja sebesar 9.446.

b) Koefisien regresi untuk variabel Motivasi sebesar 0.395 hal ini menunjukkan bahwa setiap kenaikan $1 \%$ faktor Motivasi maka akan meningkatkan Kinerja Guru sebesar $39.5 \%$.
Dari gambar di atas menunjukkan bahwa diagram pencar tidak membentuk suatu pola atau acak, dengan demikian dapat dikatakan bahwa regresi tidak mengalami gangguan heteroskedastisitas pada model regresi sehingga model regresi layak dipakai untuk mengetahui Kinerja Guru (Y) berdasarkan variabel bebasnya.

\section{Hasil dan Pembahasan}

\subsection{Analisis Regresi Linier Berganda}

Analisis regresi linier berganda digunakan untuk mengetahui berapa besar Pengaruh Motivasi, Kemampuan Manajerial Kepala Sekolah dan Iklim Organisasi Terhadap Kinerja Guru Di Sekolah Menengah Kejuruan ( SMK ) YPT Pangkalan Berandan. Analisis dilakukan dengan menggunakan bantuan SPSS versi 20 dengan output sebagai berikut : c) Koefisien regresi untuk variabel Kemampuan Manajerial Kepala Sekolah sebesar 0.307 hal ini menunjukkan bahwa setiap kenaikan $1 \%$ faktor Kemampuan Manajerial Kepala Sekolah maka akan meningkatkan Kinerja Guru sebesar $30.7 \%$.

d) Koefisien regresi untuk variabel Iklim Organisasi sebesar 0,178 hal ini menunjukkan bahwa setiap kenaikan $1 \%$ faktor Iklim Organisasi maka akan meningkatkan Kinerja Guru sebesar $17.8 \%$.

\subsection{Evaluasi}

Untuk pengujian hipotesis yang diajukan diterima atau ditolak, digunakan uji $\mathrm{F}$ dengan ketentuan jika $\mathrm{F}_{\text {hitung }}>\mathrm{F}_{\text {tabel }}$ maka $\mathrm{H}_{0}$ ditolak dan $\mathrm{H}_{1}$ diterima, sebaliknya apabila $\mathrm{F}_{\text {hitung }} \leq \mathrm{F}_{\text {tabel }}$ maka $\mathrm{H}_{0}$ diterima dan $\mathrm{H}_{1}$ ditolak. Sedangkan 
pengujian secara parsial masing-masing variabel independen dimaksudkan untuk mengetahui apakah secara individual variabel Motivasi, Kemampuan Manajerial Kepala Sekolah dan Iklim Organisasi mempunyai pengaruh yang nyata atau tidak terhadap variabel Kinerja Guru. Untuk pengujian secara parsial digunakan uji $t$ dengan ketentuan jika $t_{\text {hitung }}>t_{\text {tabel }}$ maka $\mathrm{H}_{0}$ ditolak dan $\mathrm{H}_{1}$ diterima, sebaliknya apabila $\mathrm{t}_{\text {hitung }}$ $\leq \mathrm{t}_{\text {tabel }}$ maka $\mathrm{H}_{0}$ diterima dan $\mathrm{H}_{1}$ ditolak.

\subsection{Uji Serempak}

Pengaruh Motivasi, Kemampuan Manajerial Kepala Sekolah dan Iklim Organisasi sebagai variabel bebas $(\mathrm{X})$ terhadap Kinerja Guru sebagai

\section{Tabel 5}

Hasil Uji Serempak

ANOVA $^{\mathrm{a}}$

\begin{tabular}{|rl|r|r|r|r|r|}
\hline \multicolumn{1}{|l|}{ Model } & \multicolumn{1}{|c|}{$\begin{array}{c}\text { Sum of } \\
\text { Squares }\end{array}$} & \multicolumn{1}{c|}{ df } & Mean Square & F & Sig. \\
\hline \multirow{2}{*}{1} & Regression & 604.816 & 3 & 201.605 & 70.178 & $.000^{\mathrm{b}}$ \\
& Residual & 114.911 & 40 & 2.873 & & \\
& Total & 719.727 & 43 & & & \\
\hline
\end{tabular}

a. Dependent Variable: Kinerja_Guru

b. Predictors: (Constant), Iklim_Organisasi, Kemamp_Mnj, Motivasi

Sumber: Hasil Penelitian, 2019 (Data Diolah)

Pada Tabel 5, di atas terlihat nilai signifikansi sebesar $0.000^{\mathrm{b}}$ lebih kecil dari $\alpha=0,05$, hal ini berarti bahwa variabel Motivasi dan Kemampuan Manajerial Kepala Sekolah serta Iklim Organisasi sebagai variabel bebas memiliki pengaruh yang highly significant. Secara serempak variabel Motivasi dan Kemampuan Manajerial Kepala Sekolah serta Iklim Organisasi menunjukkan pengaruh sangat nyata terhadap Kinerja Guru variabel terikat (Y) Di Sekolah Menengah Kejuruan ( SMK ) YPT Pangkalan Berandandapat dilihat pada Tabel 5.18 berikut.

Dari Tabel 5.16 dibawah, diperoleh nilai $F_{\text {hitung }}$ sebesar 70.178. Dengan menggunakan confidence interval (CI) $95 \%$ df 3:44 ( $\alpha=0.05)$ maka dari tabel distribusi $\mathrm{F}$ diperoleh nilai 2,82. Dengan demikian $\mathrm{F}_{\text {hitung }} 70.178>\mathrm{F}_{\text {tabel }} 2.82$, maka $\mathrm{H}_{0}$ ditolak dan $\mathrm{H}_{1}$ diterima, artinya variabel Motivasi, Kemampuan Manajerial Kepala Sekolah dan Iklim Organisasi sebagai variabel bebas (X) berpengaruh signifikan terhadap variabel Kinerja Guru Sekolah Menengah Kejuruan ( SMK ) YPT Pangkalan Berandan.

Tabel 6

Sekolah Menengah Kejuruan ( SMK ) YPT Pangkalan Berandan.

Selanjutnya berdasarkan nilai koefisien determinasi $\left(\mathrm{R}^{2}\right)$ diketahui besarnya pengaruh perubahan variabel Motivasi dan Kemampuan Manajerial Kepala Sekolah serta Iklim Organisasi terhadap Kinerja Guru Di Sekolah Menengah Kejuruan ( SMK ) YPT Pangkalan Berandan, sebagai berikut:

Koefisien Determinasi

Model Summary ${ }^{\mathrm{b}}$

\begin{tabular}{|l|r|r|r|r|r|r|}
\hline Model & \multicolumn{1}{|c|}{$\mathrm{R}$} & R Square & \multicolumn{1}{c|}{$\begin{array}{c}\text { Adjusted R } \\
\text { Square }\end{array}$} & $\begin{array}{l}\text { Std. Error of } \\
\text { the Estimate }\end{array}$ & \multicolumn{2}{|c|}{ Change Statistics } \\
\cline { 5 - 7 } & & & $\begin{array}{l}\text { R Square } \\
\text { Change }\end{array}$ & F Change \\
\hline 1 & $.917^{\mathrm{a}}$ & .840 & .828 & 1.695 & .840 & 70.178 \\
\hline
\end{tabular}

a. Predictors: (Constant), Iklim_Organisasi, Kemamp_Mnj, Motivasi

b. Dependent Variable: Kinerja_Guru

Nilai koefisien determinasi sebesar 0,840 berarti bahwa terhadap Kinerja Guru Sekolah Menengah Kejuruan ( SMK ) YPT Pangkalan Berandan dapat dijelaskan oleh perubahan Motivasi dan Kemampuan Manajerial Kepala Sekolah serta Iklim Organisasi sebesar 84.0\%, sedangkan sisanya sebesar $16.0 \%$ dipengaruhi oleh variable lain yang tidak dianalisis dalam penelitian ini.

\subsubsection{Uji Parsial}

Uji pengaruh variabel Motivasi dan Kemampuan Manajerial Kepala Sekolah serta Iklim Organisasi secara parsial dapat dilihat pada Tabel 5.18 berikut; 
Tabel 7

Hasil Uji Parsial

Coefficients $^{\mathrm{a}}$

\begin{tabular}{|c|c|c|c|c|c|c|}
\hline \multirow{2}{*}{\multicolumn{2}{|c|}{ Model }} & \multicolumn{2}{|c|}{ Unstandardized Coefficients } & \multirow{2}{*}{$\begin{array}{c}\begin{array}{c}\text { Standardized } \\
\text { Coefficients }\end{array} \\
\text { Beta }\end{array}$} & \multirow[t]{2}{*}{$\mathrm{t}$} & \multirow[t]{2}{*}{ Sig. } \\
\hline & & B & Std. Error & & & \\
\hline \multirow{4}{*}{1} & (Constant) & 9.446 & 1.469 & & 6.432 & .000 \\
\hline & Motivasi & .395 & .101 & .452 & 3.912 & .000 \\
\hline & Kemamp_Mnj & .307 & .080 & .407 & 3.856 & .000 \\
\hline & Iklim_Organisasi & .178 & .067 & 197 & 2.663 & .011 \\
\hline
\end{tabular}

a. Dependent Variable: Kinerja_Guru

Sumber: Hasil Penelitian, 2019 (Data Diolah)

Dari Tabel 5.20 diperoleh nilai $\mathrm{t}_{\text {hitung }}$ masingmasing variabel. Nilai $t_{\text {hitung }}$ tersebut selanjutnya dibandingkan dengan nilai $t_{\text {tabel }}$ pada tingkat kepercayaan $95 \%$ atau $\alpha=0,05$. Nilai $t_{\text {tabel }}$ pada df 3:44 dengan $\alpha=0,05$ adalah 2.015. Pengaruh parsial dari variabel Motivasi $\left(\mathrm{X}_{1}\right)$ diperoleh dengan nilai $t_{\text {hitung }}$ sebesar 3.912, dengan demikian $t_{\text {hitung }}>t_{\text {tabel }}(3.912>2.015)$ dengan nilai signifikan sebesar $0.000<0.05$, maka $\mathrm{H}_{0}$ ditolak dan $\mathrm{H}_{1}$ diterima, yang berarti bahwa variabel Motivasi $\left(\mathrm{X}_{1}\right)$ berpengaruh positif dan signifikan terhadap Kinerja Guru Sekolah Menengah Kejuruan ( SMK ) YPT Pangkalan Berandan. Hal ini berarti bahwa apabila Motivasi $\left(\mathrm{X}_{1}\right)$ meningkat atau semakin baik maka Kinerja Guru Sekolah Menengah Kejuruan ( SMK ) YPT Pangkalan Berandanjuga akan meningkat.

Pengaruh parsial dari variabel Kemampuan Manajerial Kepala Sekolah $\left(\mathrm{X}_{2}\right)$ diperoleh dengan nilai $t_{\text {hitung }}$ sebesar 3.856, dengan demikian $t_{\text {hitung }}>t_{\text {tabel }}(3.856>2.015)$ dengan nilai signifikan sebesar $0.000<0.05$, maka $\mathrm{H}_{0}$ ditolak dan $\mathrm{H}_{1}$ diterima, yang berarti bahwa variabel Kemampuan Manajerial Kepala Sekolah $\left(\mathrm{X}_{2}\right)$ berpengaruh positif dan signifikan terhadap Kinerja Guru Sekolah Menengah Kejuruan ( SMK ) YPT Pangkalan Berandan. Hal ini berarti bahwa apabila Kemampuan Manajerial Kepala Sekolah $\left(\mathrm{X}_{2}\right)$ meningkat atau semakin baik maka Kinerja Guru Sekolah Menengah Kejuruan ( SMK ) YPT Pangkalan Berandanjuga akan meningkat.

Pengaruh parsial dari variabel Iklim Organisasi $\left(\mathrm{X}_{3}\right)$ diperoleh dengan nilai $\mathrm{t}_{\text {hitung }}$ sebesar 2.663, dengan demikian $t_{\text {hitung }}>t_{\text {tabel }}$ $(2.663>2.015)$ dengan nilai signifikan sebesar $0.011<0.05$, maka $\mathrm{H}_{0}$ ditolak dan $\mathrm{H}_{1}$ diterima, yang berarti bahwa variabel Iklim Organisasi $\left(\mathrm{X}_{3}\right)$ berpengaruh positif dan signifikan terhadap Kinerja Guru Sekolah Menengah Kejuruan (
SMK ) YPT Pangkalan Berandan. Hal ini berarti bahwa apabila Iklim Organisasi $\left(\mathrm{X}_{3}\right)$ meningkat atau semakin baik maka Kinerja Guru Sekolah Menengah Kejuruan ( SMK ) YPT Pangkalan Berandanjuga akan meningkat.

Berdasarkan hasil analisis diketahui bahwa nilai koefisien regresi yang paling tinggi adalah variabel Motivasi $\left(\mathrm{X}_{1}\right)$ sebesar 0.452 atau $45.2 \%$. Hal ini berarti bahwa Motivasi $\left(\mathrm{X}_{1}\right)$ berpengaruh lebih dominan terhadap Kinerja Guru Sekolah Menengah Kejuruan ( SMK ) YPT Pangkalan Berandan.

\section{Kesimpulan}

Dari hasil analisis yang telah dibahas, maka ditarik kesimpulan sebagai berikut:

a) Motivasi ( $\left.\mathrm{X}_{1}\right)$ berpengaruh positif dan signifikan terhadap Kinerja Guru Sekolah Menengah Kejuruan ( SMK ) YPT Pangkalan Berandan dengan nilai koefisien regresi sebesar 0.452 atau $45.2 \%$.

b) Kemampuan Manajerial Kepala Sekolah $\left(\mathrm{X}_{2}\right)$ berpengaruh positif dan signifikan terhadap Kinerja Guru Sekolah Menengah Kejuruan ( SMK ) YPT Pangkalan Berandan dengan nilai koefisien regresi sebesar 0.407 atau $40.7 \%$.

c) Iklim Organisasi $\left(\mathrm{X}_{3}\right)$ berpengaruh positif dan signifikan terhadap Kinerja Guru Sekolah Menengah Kejuruan ( SMK ) YPT Pangkalan Berandan dengan nilai koefisien regresi sebesar 0.197 atau $19.7 \%$.

d) Motivasi dan Kemampuan Manajerial Kepala Sekolah serta Iklim Organisasi berpengaruh signifikan terhadap Kinerja Guru Sekolah Menengah Kejuruan ( SMK ) YPT Pangkalan Berandan dengan nilai koefisien determinasi sebesar 0,840 atau $84.0 \%$.

\section{DAFTAR PUSTAKA}

Amiyati. 2010. Hubungan Antara Kompetensi Pedagigik Guru Dengan Motivasi Belajar 
Siswa Pada Mata Pelajaran Biologi (Studi Korelasi Pada Siswa Kelas XI IPA SMA Negeri I Cilegon Tahun Ajaran 2009 2010), Skripsi Sarjan Universitas Pendidikan Indonesia Bandung : Tidak Diterbitkan.

Atmodiwirio, Soebagio. 2010. Manajemen Pendidikan Indonesia. Jakarta : Balai Pustaka.

Azwar, Saifuddin. 2007. Metode Penelitian. Yogyakarta : Pustaka Pelajar.

Danim, Sudarwan. 2012. Menjadi Peneliti Kualitatif. Bandung : CV. Pustaka Setia.

Depdikbud. 2004 Tentang Standard Kompetensi Pendidikan. Jkarta : Puskur.Dit. PTKSD.

Depdiknas. 2004. Kurikulum Tingkat Satuan Pendidikan. Jakarta : Dikmenum Depdiknas.

Fattah, Nanang. 2010. Analisis Kebijakan Pendidikan. Bandung : PT. Remaja Rosdakarya.

George dan Jones. 2015. Understanding and Managing Organizational Behavior 4th Edition. New York : pearson Prentice Hall.

Handoko, T Hani. 2010. Menejemen Personalia dan Sumber Daya Manusia. Yogyakarta : BPFE.

Indiono, D.T. 2013. Hubungan Keterampilan Manajerial Kepala Sekolah dengan Kinerja Guru Pembimbing Pada SMU Negeri di Kabupaten Kendal. Tesis : Tidak Dipublikasikan.

Kaplan, R.M. dan Saccuzzo, D.P. 2013. Psychological Testing Principles, Application and Issues, Sixth Edition. USA : Wadsworth.

Koesmono. 2015. Pengaruh Budaya Organisasi Terhadap Motivasi dan Kepuasan Kerja Serta Kinerja Karyawan : Jurnal Manajemen dan Kewirausahaan, Vol.7 No.2, September 2015.

Law, S. And Glover, D. 2011. Educational Leadership and Learning Practice Policy and Research. England ; Open University Press.

Lussier, R.N. 2015. Human Relations in Organizations: Applications and Skills Building (6th Ed). New York : Mc Graww Hill/Irwin.

Manullang, M. 2015. Dasar - Dasar Manajemen. Jogjakarta : Gadjah Mada University Press.

Mathias Robert. 2012. Manajemen Sumber Daya Manusia Edisi Pertama. Jakarta : Salemba Empat.
Mathias Robert, L., Jackson John H. 2016. Human Resource Management (Terjemahan) Buku 2 Edisi kesembilan. Jakarta : Salemba Empat.

Michael, Amstrong. 2010. A Handbook of Human Resource Management Practice Edition. Alih Bahasa Oleh Intan. London : Kogan Page.

Mulyadi. 2010. Pengaruh Kompetensi dan Motivasi Terhadap Kinerja Guru Pada SMK 1 Purwakarta. Jurnal.

Munandar, Utami. 2016. Kumpulan Metode Pembelajaran. Bandung : Satu Nusa.

Munfaat, A. 2011. Hubungan Kemampuan Manajerial Kepala Sekolah dan Motivasi Kerja Guru dengan Kinerja guru SLTP Negeri di Kabupaten Pati. Tesis : Tidak Dipublikasikan.

Peraturan Mentri Pendidikan Nasional Nomor 13 Tahun 2007 Tentang Standar Kepala Sekolah/Madrasah. Jakarta.

Rizky, Mhd. 2013. Pengaruh Kemampuan Manajerial Kepala Sekolah, Motivasi dan Iklim Organisasi terhadap Kinerja Guru SMAN 2 Genteng. Tesis : Tidak Diterbitkan.

Robbins, Stephen P. 2012. Organizational Behaviour, Concept, Controversies Aplications. USA: Prentice Hall Inn.

Robbins, Stephen P. 2013. The Priciple of Organizational Behaviour. USA: Prentice Hall Inn.

Robbins, Stephen P. 2016. Perilaku Organisasi. Edisi Revisi. Jakarta : Gramedia.

Robbins, P.Stephen dan Timothy A. Judge. 2017. Perilaku Organisasi. Salemba Empat. Jakarta.

Rosmiani. 2016. Etos Kerja. Jakarta : Gramedia. Russel and Rucky. 2012. Human Resource Management. New Jersey : Pearson Education.

Sedarmayanti. 2011. Sumber Daya Manusia dan Produktivitas Kerja, Cetakan Kedua. Bandung : Mandar Maju.

Setiadi. 2011. Metodologi Penelitian : Konsep dan Penulisan. Yogyakarta : Graha Ilmu.

Shiddiq, Djauhar M. 2016. Defenisi Pembelajaran. Bandung : Pt. Remaja Rosdakarya.

Siagian, Sondang P. 2014. Teori Pengembangan Organisasi. Jakarta : Bumi Aksara.

Simamora, Bilson. 2014. Riset Pemasaran Manajemen. Jakarta : Gramedia Utama.

Sobandi, A. 2015. Pengaruh Gaya Manajerial Kepala Sekolah, Iklim Organisasi Dan 
Karir Individu Terhadap Kinerja Mengajar Guru SMKN Bidang Keahlian Bisnis Dan Manajemen Di Kota Bandung. Tesis : Tidak Diterbitkan.

Soekartawi. 2015. Manajemen Pendidikan : teori dan Aplikasi. Jakarta : Rajawali Press.

Steers, R.M. 2011. Introduction to Organizational Behavior. New York : Harper Collins.

Stringer, Robert. 2012. Leadership and Organizational Climate. New York : Prentice Hall.

Sudjana. 2012. Metode Statistika. Bandung : Tarsito.

Sugiyono. 2014. Statistika Untuk Penelitian. Bandung : Alfabeta.

Sugiyono. 2010. Metode Penelitian Bisnis Cetakan kesembilan. Bandung: Alfabeta.

Sugiyono. 2014. Metode Penelitian Pendidikan Pendekatan Kuantitatif, Kualitatif dan R\&D. Bandung : Alfabeta.

Sugiyono. 2017. Metode Penelitian Kualitatif dan Kuantitatif, Cetakan kesembilan. Bandung : Alfabeta.

Suharyadi, Purwanto. 2004. Statistika Untuk Ekonomi dan Keuangan. Jakarta : Salemba Empat.

Sumantri, Arif. 2011. Metode Penelitian. Edisi Pertama. Jakarta : Kencana.

Sumarningsih. 2011. Pengaruh fasilitas belajar, motivasi dan iklim organisasi terhadap kinerja guru Sekolah Dasar Negeri 04070024 Yogyakarta. Tesis : Tidak Diterbitkan.

Sumodiningrat, Gunawan. 2001. Menejemen Pendidikan. Yogyakarta : Pustaka Pelajar.

Supardi. 2014. Kinerja Guru. Jakarta : PT. Raja Grafindo Persada.
Supeno. 2015. Manajemen Ilmu pendidikan. Jakarta : Rineka Cipta.

Susanto, Ahmad. 2010. Pemikiran Pendidikan. Jakarta : Salemba Empat.

Sutiko, S. 2016. Metode dan Model Pembelajaran. Lombok : Holistika.

Tilaar, H. A. R. 2011. Pendidikan Kebudayaan dan Masyarakat Madani Indonesia. Bandung : Remaja Rosdakarya.

Triatna. 2011. Visionary Leadership Menuju Sekolah Efektif. Jakarta : Bumi Aksara.

Undang - Undang Republik Indonesia Nomor 20 Tahun 2003 Tentang Sistem Pendidikan Nasional. Jakarta : Dharma Bakti.

Uno, B. Hamzah. 2012. Teori Motivasi dan pengukurannya. Jakarta : Pt. Bumi Aksara.

Usman, Husaini. 2012. Manajemen dan Riset Pendidikan, Edisi Keempat. Jakarta : Bumi Aksara.

Usman, Husaini. 2015. Manajemen Teori, Peraktik dan Riset Pendidikan, Edisi Keempat. Jakarta : Bumi Aksara.

Wagner, John A. \& Hollenbeck, John R. 2010. Organizational Behavior : Securing Competitive Advantage. New York : Routledge.

Wahjosumidjo. 2002. Kepemimpinan Kepala Sekolah Tinjauan Tioritik dan Permasalahannya. Jakarta : Rajawali Pers.

Wahjosumidjo. 2012. Kepemimpinan Kepala Sekolah. Jakarta : Raja Grafindo Persada.

Wirawan. 2010. Konflik dan Manajemen Konflik : Teori, Aplikasi dan Penelitian. Jakarta : Salemba Humanika.

Wungu, Jiwo dan Brotoharsojo, Hartono. 2013. Tingkatkan Kinerja Perusahaan dengan Merit System. Jakarta: Pt. Raja Grafindo Persada. 